Egyptian Journal of Aquatic Biology \& Fisheries

Zoology Department, Faculty of Science,

Ain Shams University, Cairo, Egypt.

ISSN $1110-6131$

Vol. 23(4): $11-21$ (2019)

www.ejabf.journals.ekb.eg

\title{
Relationships between fish and otolith dimensions of Epinephelus summana (Forsskål, 1775) and Cephalopholis argus (Schneider, 1801) from the Egyptian Red Sea coast
}

\author{
Sahar F. Mehanna ${ }^{1 *}$; Yassein A. A. Osman ${ }^{1}$; Magdy T. Khalil ${ }^{2}$; Arafa Hassan ${ }^{1}$ \\ 1- National Institute of Oceanography and Fisheries, Egypt \\ 2- Faculty of Science, Ain Shams University, Egypt \\ *Corresponding author: Sahar_mehanna@yahoo.com
}

\section{ARTICLE INFO \\ Article History: \\ Received: Sep.17, 2019 \\ Accepted: Oct. 5, 2019 \\ Online: Oct. 8, 2019}

\section{Keywords:}

Otolith morphology

Epinephelus summana

Cephalopholis argus

Egyptian Red Sea

\begin{abstract}
Otolith morphology analysis is one of the main tools used for fish or stock identification. Moreover, it is used in the stomach content studies for the identification of prey fish and their size according to the relationship between fish and otolith sizes. In the present study, the relationships between fish length and otolith morphological dimensions were investigated for Epinephelus summana (Forsskål, 1775) and Cephalopholis argus (Schneider, 1801) (family: Serranidae). A total of 170 E. summana and 154 E. argus (i.e 340 and 308 sagittal otoliths for E. summana and E. argus respectively) were sampled from the coast of the Egyptian Red Sea off Shalateen fishing ground. The statistical analysis was done by generalized linear models for the relationship between body length and weight and otolith morphology descriptors (length, width, area and perimeter) and shape indices (Aspect ratio, Compactness, rectangularity, Sulcus and Ostium). The results revealed that there is significantly correlation between the TL of fish and the eleven morphology descriptors and shape indices, where the side effect was $\mathrm{p}<0.05$. Also, this study added new information for the region because of lack of data for the relationships between otolith morphometric and fish length.
\end{abstract}

\section{INTRODUCTION}

Serranid fishes consider as one of the most commercially important fishes in the Red Sea. Family Serranidae comprises a large number of species and at least 31 of them are found in the Red Sea (Randall and Ben Tauvia, 1983).

Epinephelus summana (Forsskål, 1775), distribute at a shallow protected coralreefs area, especially, in both The Red Sea and the Gulf of Aden and is more closely to the allopatric E. ongus of the Indo-west Pacific, (Heemstra and Randall, 1993). There are very few studies on its biology and dynamics are available.

Cephalopholis argus (Schneider, 1801) is a common tropical species found in a different habitat of coral reef from $1 \mathrm{~m}$ to least $40 \mathrm{~m}$, and the most widely distributed of the groupers This species is important to artisanal fisheries, throughout the IndoWest Pacific region (Heemstra and Randall, 1993).

Among fisheries management requirements is the age determination which carried out by hard parts like scales, otolith, vertebra, etc. The fisheries researchers have used the otolith to estimate the age and growth of fishes because of the clear and 
distinct growth rings of sagittal (Chilton and Beamish, 1982; Summerfelt and Hall, 1987). The otoliths are located in the head of teleost fishes and found in paierd calcareous structures; it is may be useful in the study of biological fish, ecological and fisheries science. Age and growth, movement and varied habitates, popoulation stock and level of trophic ecology were estimated by otolith (Tuset et al., 2003a; Parisi-Baradad et al., 2005; Short et al. 2006; Duarte-Neto et al., 2008; Morat et al., 2012; Radhakrishnan et al., 2012; Sadighzadeh et al., 2012; Lord et al., 2012; Bani et al., 2013; Bostanci et al., 2015; Mehanna et al., 2016; Osman et al., 2018).

The otoliths are widely used tools in the identification and comparative taxonomy of fishes because it is large and inter-specific variability of fish otolith (Battaglia et al., 2010). The morphometric measurements of sagittal otolith has been used in many studies to compare between the closely vareid species (Tuset et al., 2003a; Ponton 2006; Short et al., 2006; Skeljo and Ferri, 2012; Wakefield et al., 2014; Zhuang et al., 2015; Mehanna et al., 2016) and between populations of a single species in marine and freshwater environments (Duarte-Neto et al., 2008; Shepard et al., 2010; Zorica et al., 2010; Zhang et al., 2013; Zischke et al., 2016).

There is rare available information concerning the differentiations of grouper species from the Egyptian Red Sea using otolith morphometric. Furthermore, the otolith outline shape indices and measurements of grouper from the Red Sea have never previously been estimated. Thus, this study may be the first to distinguish grouper species using otolith dimensions and their relationships with fish size and otolith size. The main objectives are to determine the otolith dimensions and indices of two serranid species and their relation with the fish length as well as to distinguish these two species based on the otolith shape and dimensions off the Egyptian coast of the Red Sea.

\section{MATERIALS AND METHODS}

Fish samples were randomly collected from the commercial catch of the artisanal fishery landed in the southern Red Sea at Shalateen fishing port, which is located $520 \mathrm{~km}$ south of Hurghada (Fig. 1). Sampling procedure was done twice each month during the period from March 2018 to February 2019. The fishing method that catch these species at Shalateen fishing ground was the hook and line fishery. The total fish length was measured to the nearest $\mathrm{mm}$, and fish weight (W) was recorded to the nearest $0.01 \mathrm{~g}$. Then, the sex was recorded. Sagittal otoliths (340 and 308 left and right otoliths for E. summana and $C$. argus, respectively; Fig. 2) were extracted from the inner ear of 170 and 154 specimens of E. summana and C. argus, respectively, then the otolith cleaned and dried until investigation. Otolith weight (OW) for each head side was measured using a digital balance AS220 k/1 to the nearest $0.0001 \mathrm{~g}$. Otolith morphologies were analysed by using a stereomicroscopic (Carl ZIESS v20) with camera Zeiss axiocam ERC 5s (5 mega pexils). Otolith measurements (Fig. 2); Otolith length $(\mathrm{OL}, \mathrm{mm})$, otolith area $\left(\mathrm{OA}, \mathrm{mm}^{2}\right)$, otolith perimeter (OP, mm), sulcus (SU), ostuim (OS), Aspect ratio (AR), Compactness (C) and rectangularity (RE) ) the otolith outline (Fig. 3) were extracted by using ImageJ 1.46r analysis software (Tuset et al. 2003b; Lombarte et al. 2006; Rohlf, 2006; Short et al. 2006; Bilge and Gülşahin, 2014; Yilmaz et al. 2014; Mehanna et al. 2016; Zischke et al. 2016; Osman et al. 2018; Mahé et al. 2018). The statistical analysis was investigated by different ways such the statistical description for minimum, maximum, and means, the linear regression between otolith outline and fish size. Finally, the generalized linear models (GLM; McCullough and Nelder, 1999) were 
modelled the relationship of body length with the otolith outline indices of according to the side $(\mathrm{S})$ :

Model "Side*Wt + Side*OL + Side*OH+ Side*OS+ Side*OO+ Side*OCA + Side*OA $^{*}$ Side*Per+ Side*AS+ Side*CO+ Side*ER"

Statistical analyses were performed in the statistical environment SPSS18.

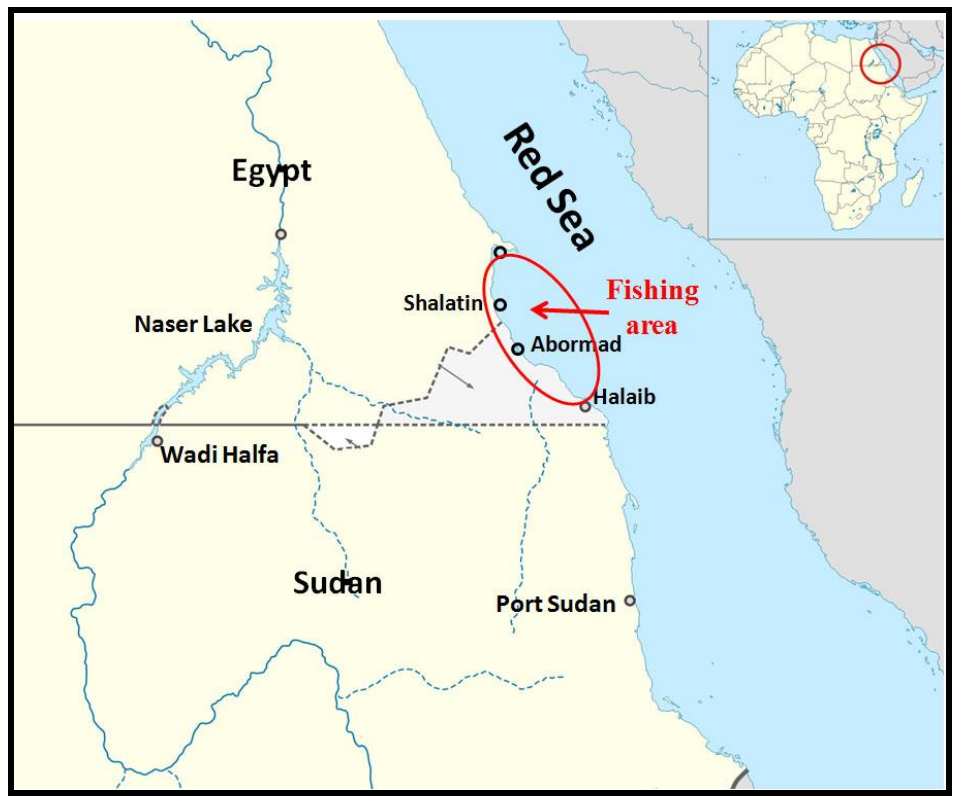

Fig. 1: Red Sea sector of Egypt showing the study area

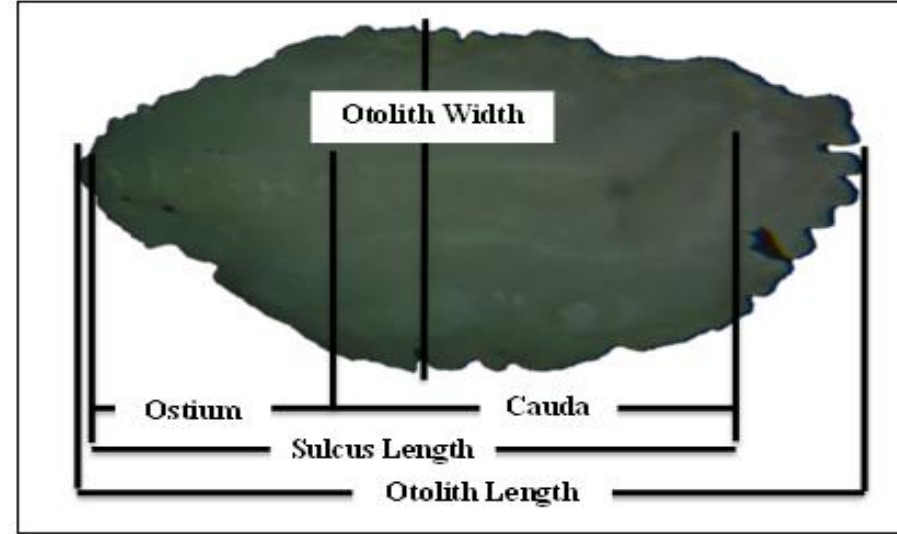

Fig. 2: Otolith morphometrics of Epinephelus summana and Cephalopholis argus from the Egyptian Red Sea, Egypt.

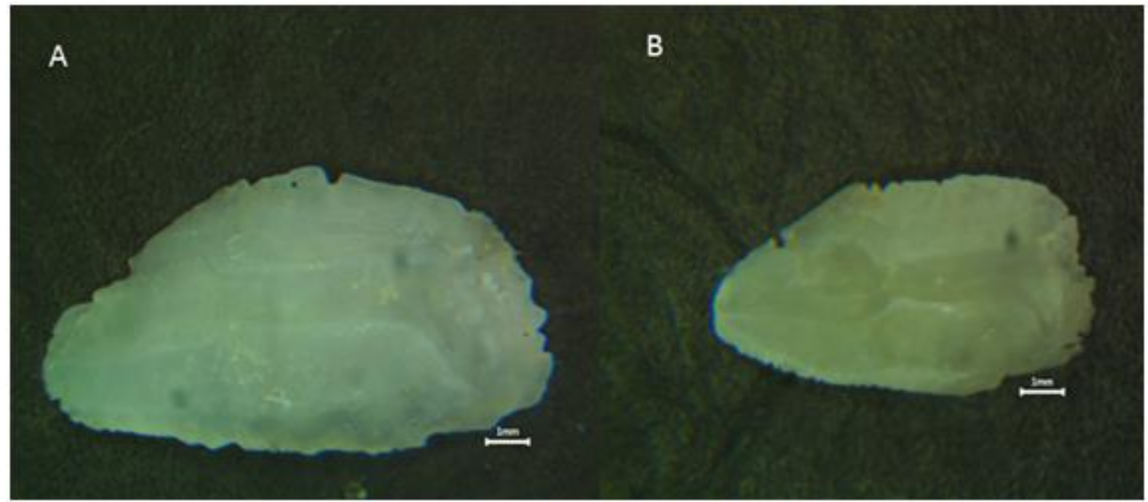

Fig. 3: Otolith shapes of the two grouper species investigated; (A) E. summana (Left otlith $\mathrm{TL}=$ $30.3 \mathrm{~cm}, \mathrm{OWt}=0.1014 \mathrm{~g}, \mathrm{OL}=9.63 \mathrm{~mm}, \mathrm{OH}=5.06 \mathrm{~mm}$ ) and $(\mathrm{B})$ C. argus $($ Left otlith $\mathrm{TL}=$ $35.7 \mathrm{~cm}, \mathrm{OWt}=0.0473 \mathrm{~g}, \mathrm{OL}=8.51, \mathrm{OH}=3.91 \mathrm{~mm})$ 


\section{RESULTS}

The total length (TL) and body weight of the two investigated species varied between 20.6 to 60.2 and from 22.4 to $48.5 \mathrm{~cm}$ for Epinephelus summana and Cephalopholis argus, respectively. While the weight of the fish ranged between 167 and $3875 \mathrm{~g}$ and between 171 and $1894.8 \mathrm{~g}$ for E. summana and C. argus, respectively. E. summana was presented by higher number of specimens than $C$. argus during the study period. Table 1 provides the overall basic statistics on the size and weight ranges, the otolith lengths, weights and heights for two grouper species.

The statistical description for both left and right otolith measurements (minimum, maximum, mean, standard error and standard deviation). The otoliths of $C$. argus were smaller than those of E. summana, where the otoliths mean lengths were varied from $10.84 \pm 1.61$ and $10.82 \pm 1.65$ for left and right of E. summana, respectively, and from $8.23 \pm 0.91$ and $8.20 \pm 0.90$ for left and right of C. argus respectively. The otolith area for E. summana (ranging from 22.75 to $68.36 \mathrm{~mm}$ for both left and right otolith) was greater than that of C. argus (ranging from 20.07 to $39.99 \mathrm{~mm}$ for both left and right otolith). Aslo, the otolith widths were varied with values $5.19 \pm 0.77,5.19 \pm 0.77,4.01 \pm 0.57$ and $4.01 \pm 0.58$ for both left and right otolith of $E$. summana and $C$. argus respectively. The overall otolith measurements of $E$. summana were greater than those of $C$. argus in all sampled fish.

Table 1: Mean and standard deviation and range (minimum- maximum) of the otolith dimension of Epinephelus summana and Cephalopholis argus from the Egyptian Red Sea, Egypt.

\begin{tabular}{|c|c|c|c|c|c|c|}
\hline \multicolumn{2}{|r|}{ Left } & \multicolumn{4}{|c|}{ Right } & \multirow[b]{2}{*}{ St. E } \\
\hline Species & Min. - Max. & Mean \pm SD & St. E & Min. - Max. & Mean \pm SD & \\
\hline \multicolumn{7}{|c|}{ E. summana } \\
\hline \multicolumn{7}{|c|}{ N. $=170$} \\
\hline BW & $167.00-3875.20$ & $842.08 \pm 852.38$ & 74.76 & & & \\
\hline TL & $20.60-60.20$ & $34.62 \pm 9.37$ & 0.82 & & & \\
\hline OW & $0.0324-0.1811$ & $0.0834 \pm 0.0410$ & 0.0036 & $0.0307 \pm 0.1811$ & $0.0842 \pm 0.0410$ & 0.0036 \\
\hline $\mathrm{OL}$ & $8.05-13.71$ & $10.84 \pm 1.61$ & 0.14 & $7.92 \pm 13.71$ & $10.82 \pm 1.65$ & 0.14 \\
\hline $\mathrm{OH}$ & $3.78-6.86$ & $5.19 \pm 0.77$ & 0.07 & $3.86 \pm 6.87$ & $5.19 \pm 0.77$ & 0.07 \\
\hline OS & $7.22-12.47$ & $9.67 \pm 1.64$ & 0.14 & $7.12 \pm 12.47$ & $9.68 \pm 1.68$ & 0.15 \\
\hline $\mathrm{OO}$ & $2.08-4.98$ & $3.95 \pm 0.73$ & 0.06 & $2.14 \pm 5.87$ & $3.84 \pm 0.93$ & 0.08 \\
\hline $\mathrm{OC}$ & $4.07-7.88$ & $5.72 \pm 1.10$ & 0.1 & $3.96 \pm 8.26$ & $5.84 \pm 1.04$ & 0.09 \\
\hline OA & $22.75-68.36$ & $38.71 \pm 10.47$ & 0.92 & $22.71 \pm 68.36$ & $38.69 \pm 10.47$ & 0.92 \\
\hline OP & $20.62-38.89$ & $27.56 \pm 4.51$ & 0.40 & $20.62 \pm 38.89$ & $27.56 \pm 4.51$ & 0.40 \\
\hline AS & $0.42-0.53$ & $0.48 \pm 0.19$ & 0.017 & $0.42-0.59$ & $0.481 \pm 0.24$ & 0.021 \\
\hline $\mathrm{CO}$ & $16.19-23.41$ & $19.86 \pm 1.82$ & 0.16 & $16.19-3.45$ & $19.87 \pm 0.183$ & 0.16 \\
\hline RE & $0.51-0.94$ & $0.69 \pm 0.086$ & 0.008 & $0.51-0.94$ & $0.69 \pm 0.90$ & 0.008 \\
\hline \multicolumn{7}{|l|}{ C. argus } \\
\hline \multicolumn{7}{|c|}{ No. $=154$} \\
\hline BW & $171.00-1894.80$ & $620.49 \pm 347.64$ & 30.61 & & & \\
\hline $\mathrm{TL}$ & $22.40-46.50$ & $32.16 \pm 5.27$ & 0.46 & & & \\
\hline OW & $.0187-0.860300$ & $.0562 \pm 0.104600$ & 0.011 & $.0187-0.996500$ & $.0651 \pm 0.138100$ & 0.0146 \\
\hline OL & $6.26-10.63$ & $8.23 \pm 0.91$ & 0.1 & $6.26-10.67$ & $8.20 \pm 0.90$ & 0.09 \\
\hline $\mathrm{OH}$ & $3.02-5.53$ & $4.01 \pm 0.57$ & 0.06 & $3.02-5.45$ & $4.01 \pm 0.58$ & 0.06 \\
\hline OS & $5.35-9.38$ & $7.10 \pm 0.89$ & 0.09 & $5.35-9.34$ & $7.09 \pm 0.89$ & 0.09 \\
\hline $\mathrm{OO}$ & $1.98-4.57$ & $3.12 \pm 0.61$ & 0.06 & $1.98-4.57$ & $3.12 \pm 0.63$ & 0.07 \\
\hline $\mathrm{OC}$ & $3.04-5.10$ & $3.99 \pm 0.46$ & 0.05 & 2.93-5.09 & $3.97 \pm 0.45$ & 0.05 \\
\hline $\mathrm{OA}$ & 20.07-39.99 & $25.42 \pm 5.62$ & 0.59 & 20.07-39.97 & $25.42 \pm 5.62$ & 0.59 \\
\hline OP & $16.04-26.94$ & $20.76 \pm 2.79$ & 0.29 & $16.04-26.93$ & $20.74 \pm 2.79$ & 0.29 \\
\hline AS & $.38-0.690$ & $0.488 \pm 0.045$ & 0.005 & $0.39-0.70$ & $0.489 \pm 0.046$ & 0.005 \\
\hline $\mathrm{CO}$ & $12.81-20.61$ & $17.149 \pm 1.900$ & 0.200 & $12.81-20.59$ & $17.122 \pm 1.905$ & 0.201 \\
\hline RE & $0.59-1.03$ & $0.772 \pm 0.093$ & 0.010 & $0.59-1.03$ & $0.775 \pm 0.096$ & 0.010 \\
\hline
\end{tabular}

The correlation between otolith morphometric and fish total length of the two grouper species was found to be linear (otolith variables $=a+b^{* T L}$ ) with high 
correlation (Table 2). All regressions were highly significant, and the analysis of otolith morphometric parameters versus TL indicated that the regression models explained nearly all of the variance that best fit TL. The correlations of two species were fluctuated through the different otolith morphology. The correlation coefficient $\left(\mathrm{r}^{2}\right)$ varied between 0.012 and 0.919 for left aspect ratio and right otolith width of $E$. summana, respectively, and from 0.017 to 0.953 for left aspect ratio and otolith perimeter of $C$. argus. The otolith perimeter of $C$. argus was highly correlated with fish length $\left(r^{2}=0.953\right)$. The results indicated that the relationship between fish size and otolith morphological measurements for both left and right otolith were showed a good linear regression.

Table 2: The relationship between fish length and TL and each otolith descriptor for Epinephelus summana and Cephalopholis argus from the Red Sea, Egypt

\begin{tabular}{|c|c|c|}
\hline Otolith descriptors & Relationship between TL and otolith descriptor & $\mathrm{R}^{2}$ \\
\hline \multirow{3}{*}{$\mathbf{O W t}$} & E. summana & \\
\hline & Left side $\mathrm{TL}=2.0874+0.5 \mathrm{~W}$ & 0.8126 \\
\hline & Right side $\mathrm{TL}=2.0737+0.4896 \mathrm{~W}$ & 0.7889 \\
\hline \multirow{2}{*}{$\mathbf{O L}$} & Left side $\mathrm{TL}=-0.108+1.5855 \mathrm{OL}$ & 0.8889 \\
\hline & Right side $\mathrm{TL}=-0.0234+1.505 \mathrm{OL}$ & 0.8588 \\
\hline \multirow{2}{*}{$\mathbf{O H}$} & Left side $\mathrm{TL}=0.3598+1.6401 \mathrm{OH}$ & 0.9189 \\
\hline & Right side $\mathrm{TL}=0.3763+1.6173 \mathrm{OH}$ & 0.9097 \\
\hline \multirow{2}{*}{ Sulcus } & Left side $\mathrm{TL}=0.1915+1.3621 \mathrm{OS}$ & 0.8474 \\
\hline & Right side $\mathrm{TL}=0.2501+1.3022 \mathrm{OS}$ & 0.8232 \\
\hline \multirow{2}{*}{ Ostium } & Left side $\mathrm{TL}=0.9228+1.023500$ & 0.6478 \\
\hline & Right side $\mathrm{TL}=1.0652+0.805100$ & 0.6298 \\
\hline \multirow{2}{*}{ Cauda } & Left side $\mathrm{TL}=0.7286+1.0633 \mathrm{OC}$ & 0.6703 \\
\hline & Right side $\mathrm{TL}=0.7411+1.0328 \mathrm{OC}$ & 0.5649 \\
\hline \multirow{2}{*}{$\mathbf{O A}$} & Left side $\mathrm{TL}=0.1013+0.9051 \mathrm{OA}$ & 0.8504 \\
\hline & Right side $\mathrm{TL}=0.1035+0.9037 \mathrm{OA}$ & 0.8492 \\
\hline \multirow{2}{*}{$\mathbf{O P}$} & Left side $\mathrm{TL}=-0.5801+1.4674 \mathrm{OP}$ & 0.8808 \\
\hline & Right side TL $=-0.5803+1.46760 \mathrm{P}$ & 0.8808 \\
\hline \multirow{2}{*}{$\mathbf{A S}$} & Left side $\mathrm{TL}=-0.5902 \mathrm{AS}+1.3249$ & 0.0119 \\
\hline & Right side $\mathrm{TL}=-0.5705 \mathrm{AS}+1.3317$ & 0.0174 \\
\hline \multirow{2}{*}{$\mathbf{C O}$} & Left side $\mathrm{TL}=-0.6929+1.7046 \mathrm{CO}$ & 0.519 \\
\hline & Right side $\mathrm{TL}=-0.6822+1.696 \mathrm{CO}$ & 0.5172 \\
\hline \multirow{3}{*}{ RE } & Left side $\mathrm{TL}=1.3786-0.8022 \mathrm{RE}$ & 0.2204 \\
\hline & Right side $\mathrm{TL}=1.3836-0.7787 \mathrm{RE}$ & 0.2242 \\
\hline & C. argus & \\
\hline \multirow{2}{*}{$\mathbf{W}$} & Left side $\mathrm{TL}=2.101+0.412 \mathrm{~W}$ & 0.8924 \\
\hline & Right side $\mathrm{TL}=2.098+0.409 \mathrm{~W}$ & 0.8343 \\
\hline \multirow{2}{*}{$\mathbf{O L}$} & Left side $\mathrm{TL}=0.181+1.451 \mathrm{OL}$ & 0.8628 \\
\hline & Right side $\mathrm{TL}=0.181+1.453 \mathrm{OL}$ & 0.8343 \\
\hline \multirow{2}{*}{$\mathbf{O H}$} & Left side $\mathrm{TL}=0.859+1.079 \mathrm{OH}$ & 0.7119 \\
\hline & Right side $\mathrm{TL}=0.871+1.058 \mathrm{OH}$ & 0.7098 \\
\hline \multirow{2}{*}{ Sulcus } & Left side $\mathrm{TL}=0.570+1.102 \mathrm{OS}$ & 0.6037 \\
\hline & Right side TL $=0.59+1.0767 \mathrm{OS}$ & 0.5784 \\
\hline \multirow{2}{*}{ Ostium } & Left side $\mathrm{TL}=1.239+0.547 \mathrm{OO}$ & 0.3616 \\
\hline & Right side $\mathrm{TL}=1.241+0.545 \mathrm{OO}$ & 0.3877 \\
\hline \multirow{2}{*}{ Cauda } & Left side $\mathrm{TL}=0.8300+1.1300 \mathrm{OC}$ & 0.5164 \\
\hline & Right side $\mathrm{TL}=0.917+0.986 \mathrm{OC}$ & 0.3943 \\
\hline \multirow{2}{*}{$\mathbf{O A}$} & Left side $\mathrm{TL}=0.395+0.795 \mathrm{OA}$ & 0.8454 \\
\hline & Right side $\mathrm{TL}=0.395+0.795 \mathrm{OA}$ & 0.8457 \\
\hline \multirow{2}{*}{$\mathbf{O P}$} & Left side $\mathrm{TL}=-0.182+1.282 \mathrm{OP}$ & 0.953 \\
\hline & Right side $\mathrm{TL}=-0.180+1.282 \mathrm{OP}$ & 0.953 \\
\hline \multirow{2}{*}{$\mathbf{A S}$} & Left side $\mathrm{TL}=1.5848+0.2545 \mathrm{AS}$ & 0.017 \\
\hline & Right side $\mathrm{TL}=1.621+0.3723 \mathrm{AS}$ & 0.0358 \\
\hline $\mathrm{CO}$ & Left side $\mathrm{TL}=0.2916+0.9853 \mathrm{CO}$ & 0.4148 \\
\hline
\end{tabular}




\begin{tabular}{clc}
\hline & Right side $\mathrm{TL}=0.2953+0.9828 \mathrm{CO}$ & 0.4148 \\
\multirow{2}{*}{ RE } & Left side $\mathrm{TL}=1.4543-0.4395 \mathrm{RE}$ & 0.0841 \\
& Right side $\mathrm{TL}=1.4602-0.392 \mathrm{RE}$ & 0.0708 \\
\hline
\end{tabular}

OWt , otolith weight; OL, otolith length; OH, otolith width; OSU, sulcus; OS, ostuim; OA, otolith area; OP, otolith perimeter, AR, Aspect ratio; C, compactness; RE, rectangularity.

The regression analysis between fish length and fourteen otolith shape descriptors from generalized linear model was cleared that there is a significant relationship between the total length of fish and eight otolith parameters (ostium, cauda, otolith area, otolith perimeter, compactness, the otolith weight, length and aspect ratio) $(\mathrm{P}<0.05)$ for both $E$. summana and $C$. argus (Table 3$)$.

Table 3 Generalized linear models for the relationship between TL and each otolith descriptor and the side effect for each relationship between TL and each otolith descriptor (Side effect). OWt , otolith weight; OL, otolith length; $\mathrm{OH}$, otolith width; OSU, sulcus; OS, ostuim; OA, otolith area; OP, otolith perimeter, AR, Aspect ratio; C, compactness; RE, rectangularity. Bold lines showed the significant effect $(\mathrm{P}<0.05)$.

\begin{tabular}{ccc}
\hline Otolith descriptor & \multicolumn{2}{c}{ Side effect } \\
\hline & E. summana & C. argus \\
side * OWt & $\mathbf{0 . 0 0 1}$ & $\mathbf{0 . 0 0 0}$ \\
side * OL & $\mathbf{0 . 0 0 9}$ & 0.099 \\
side * OH & 0.964 & 0.252 \\
side * OSU & 0.079 & 0.858 \\
side * OO & 0.075 & 0.789 \\
side * OCA & 0.211 & 0.857 \\
side * OA & 0.810 & 0.125 \\
side * OP & 0.957 & $\mathbf{0 . 0 2 1}$ \\
side * AS & $\mathbf{0 . 0 4 4}$ & 0.812 \\
side * CO & 0.620 & 0.968 \\
side * RE & 0.776 & 0.053 \\
\hline
\end{tabular}

\section{DISCUSSION}

The morphological measurements of the otolith of fish are the most widely used tool to identify and compare the taxonomic characteristics of fishes due to the large size and interspecific variability in fish otoliths (Nolf, 1985; Battaglia et al., 2010; Lord et al., 2012; Bostanci et al., 2015). Paleontologists, oceanographers and marine biologists have used the species specific distinctive morphology of the sagittae and their dense structure that can resist certain degree of disintegration to determine the identity of fish species found in middens, sediments and stomach content of marine birds and mammals (Fitch 1964, 1969, Tripple and Beamish 1987, Ainley et al. 1981, Treacy and Crawford 1981).

Researches in fish biology and population dynamics get huge usage of the otolith length-total length relationship (Echeverria, 1987). Furthermore, the identity of the eaten fish species and their size can be estimated from their otolith retrieved from the digestive tract of the piscivorous fishes (Aydin et al., 2004). The estimated relationship between fish length and otolith biometry can be also used to determine fish length during development based on otolith morphometry. The otoliths can remain undigested for long periods in carnivore fish stomach and is possible to estimate prey fish size based on otoliths found in the stomach (Bostanci, 2009).

The otolith dimensions - fish size relationship in the Egyptian fisheries is rarely studied. So the present study is the first to interest with the estimated the different parameters of the otoliths of the grouper species in the Egyptian Red Sea. The estimation of the specific equations provided in the present study can be useful for studies on food and feeding as well as for paleontological. 
There is little data available on otolith morphology of the two grouper species under study E. summana and $C$. argus from the Red Sea. The size range of the two grouper species in the present study was higher than that recorded in the previous studies (Osman, 2000; Mohamed, 2007). The study of relationship between otolith size and fish size varied according to the distribution region, the stock and sexes (Sparre et al., 1989; Campana and Casselman, 1993; Reichenbacher et al., 2009; Aneesh et al., 2017), also the change of ontogenetic in the life span or history (Hare and Cowen, 1995). The present work was confirmed with other studies that investigated the correlation between fish length and otolith size (Mahé et al., 2014; Mahé et al., 2016; Mehanna et al., 2016; Jawad, et al., 2017; Mapp 2017; Mahé et al., 2018; Osman et al., 2018).

The investigation of fish length and otolith and the essential role of otolith morphometric measurements in fish identification stock were recently heavily studied (Harvey et al., 2000; Tuset et al., 2003b; Lychakov et al., 2006; Sadighzadeh et al., 2014; Gündoğdu and Baylan, 2016; Mehanna et al., 2016; Mahé et al., 2018b). The strong correlation between the somatic length and otolith size suggests that somatic growth has a significant influence on the otolith growth (Jockusch, 1997; Cardinale et al., 2004). According to the current results, the correlation between TL and AR and $\mathrm{CO}$ was determined as a linear relationship, despite the relationship between TL and $\mathrm{RE}$ being determined as a nonlinear relationship. The results of generalized linear model GLM described the correlation between otolith measurements may be affected by the choice of the otolith (significant asymmetry between right and left otoliths). Generalized linear models for the relationship between TL and each otolith descriptor and the side effect on each relationship were investigated. There are no significant between the TL and some of otolith measurements while there is a significant difference for other otolith measurements such as otlith length, weight, perimeter and aspect ratio for both grouper species. The present study agreed with other studies, which reported the significant for the side effect on the select of the left and right otolith (Mahé et al., 2017; Osman et al., 2018). Considering the findings in this study, the fish length and otolith measurements parameters are useful for most verifying the role of otoliths in the identification, discrimination and taxonomic classification of fish. Also, the present results showed that the otolith shape indices significantly differed from species to species, although the indices indicate a similar pattern for both otoliths. Consequently, there are reliable with that otoliths are used for distinguish between fish species because of their form, diet, weight and growth (Tuset et al., 2008; Battaglia et al., 2010; Bacha et al., 2010).

\section{CONCLUSION}

The reported of GLM investigated in the present study may be best way to study the relationship between fish length and otolith morphometric features used to ecological study, paleontological composition, fish population dynamics, yield estimates and stomach contents of piscivorous predators. These relationships provide a reliable tool in feeding studies and also provide support to palaeontologists in their research on fish fossils.

\section{REFERENCES}

Aneesh Kumar, K.; Deepa, K.; Hashim, M.; Vasu, C. and Sudhakar, M. (2017). Relationships between fish size and otolith size of four bathydemersal fish species from the south eastern Arabian Sea, India. J. Appl. Ichthyol., 33(1): 102-107. 
Ainley, D. G.; Anderson, D.W.; Kelly, P. R. (1981). Feeding ecology of marine cormorants in southwestern North America, Condor, 83: 120-131. doi: $10.2307 / 1367418$

Aydin, R.; Calta, M.; Sen, D.; Coban, M. Z. (2004). Relationships between fish lengths and otolith length in the population of Chondrostoma regium (Heckel, 1843) inhabiting Keban Dam Lake, Pakistan Journal of Biological Sciences, 7: 1550-1553. doi: 10.3923/pjbs.2004.1550.1553

Bacha, M.; Moali, A.; Benmansour, N. E.; Brylinski, J. M.; Mahe, K. and Amara, R. (2010). Relationships between age, growth, diet and environmental parameters for anchovy (Engraulis encrasicolus L.) in the Bay of Bénisaf (SW Mediterranean, west Algerian coast). Cybium, 34(1): 47-57.

Bani, A.; Poursaeid, S. and Tuset, V. M. (2013). Comparative morphology of the sagittal otolith in three species of south Caspian gobies. J. Fish. Biol., 82(4): 1321-1332.

Battaglia, P.; Malara, D.; Romeo, T. and Andaloro, F. (2010). Relationships between otolith size and fish size in some mesopelagic and bathypelagic species from the Mediterranean Sea (Strait of Messina, Italy). Sci. Mar., 74(3): 605-612.

Bilge, G. and Gülşahin, A. (2014). Relationship between sagittal otolith size and fish size in Argentina sphyraena and Glossanodon leioglossus (Osteichthyes: Argentinidae) in the southern Aegean Sea, Turkey. Zool. Middle. East., 60(1): 24-28.

Bostanci, D. (2009). Otolith biometry - body length relationships in four fish species (chub, pikeperch, crucian carp, and common carp). Journal of Freshwater Ecology, 24: 619-624.

Bostanci, D.; Polat, N.; Kurucu, G.; Yedier, S.; Kontaş, S. and Darçin, M. (2015). Using otolith shape and morphometry to identify four Alburnus species (A. chalcoides, A. escherichii, A. mossulensis and A. tarichi) in Turkish inland waters. J Appl. Ichthyol., 31(6): 1013-1022.

Campana, S. E. and Casselman, J. M. (1993). Stock discrimination using otolith shape analysis. Can. J Fish. Aqut. Sci., 50(5): 1062.

Cardinale, M.; Doering-Arjes, P.; Kastowsky, M. and Mosegaard, H. (2004). Effects of sex, stock, and environment on the shape of known-age Atlantic cod (Gadus morhua) otoliths. Can. J of Fish. Aquat, Sci., 61(2): 158-167.

Duarte-Neto, P.; Lessa, R.; Stosic, B. and Morize, E. (2008). The use of sagittal otoliths in discriminating stocks of common dolphinfish (Coryphaena hippurus) off northeastern Brazil using multishape descriptors. ICES J Mar. Sci. Journal du Conseil, 65(7): 1144-1152.

Fitch, J. E. (1964). The fish fauna of the Playa del Rey Locality, a southern California marine Pleistocene deposit, Los Angeles City Museum of Contemporary Science, 82: 3-35.

Fitch, J. E. (1969). Fossil records of certain schooling fishes of the California current system, CALCOFI Report, 13: 71-80.

Granadeiro, J. P. and Silva, M. A. (2000). The use of otoliths and vertebrae in the identification and size-estimation of fish in predator-prey studies. Cybium, 24(4): 383-393.

Gündoğdu, S. and Baylan, M. (2016). Analyzing Growth Studies of Four Mullidae Species Distributed in Mediterranean Sea and Black Sea. Pak. J Zool., 48(2).

Hare, J. A. and Cowen, R. K. (1995). Effect of age, growth rate, and ontogeny on the otolith size-fish size relationship in bluefish, Pomatomus saltatrix, and the 
implications for back-calculation of size in fish early life history stages. Can. J Fish. Aqut. Sci., 52(9): 1909-1922.

Harvey, J. T.; Loughlin, T. R.; Perez, M. A. and Oxman, D. S. (2000). Relationship between fish size and otolith length for 63 species of fishes from the eastern North Pacific Ocean. NOAA Technical Report NMFS, 150: 1-36.

Heemstra, P. C. and Randall, J.E. (1993). FAO species catalogue, Vol. 16. Groupers of the world (Family Serranidae, Subfamily Epinephelinae). An annotated and illustrated catalogue of the grouper, rockcod, hind, coral grouper and lyretail species known to date. FAO Fisheries synopsis, 125, FAO, Rome.

Jawad, L. A.; Hoedemakers, K.; Ibáñez, A. L.; Ahmed, Y. A.; El-Regal, M. A. A. and Mehanna, S. F. (2017). Morphology study of the otoliths of the parrotfish, Chlorurus sordidus (Forsskål, 1775) and Hipposcarus harid (Forsskål, 1775) from the Red Sea coast of Egypt (Family: Scaridae). Journal of the Marine Biological Association of the United Kingdom, J Mar. Biol. Assoc. UK., 98: (4): $819-828$

Jockusch, E. L. (1997). Geographic variation and phenotypic plasticity of number of trunk vertebrae in slender salamanders, Batrachoseps (Caudata: Plethodontidae). Evolut., 51(6): 1966-1982.

Karakulak, F.; Erk, H. and Bilgin, B. (2006). Length-weight relationships for 47 coastal fish species from the northern Aegean Sea, Turkey. J. Appl. Ichthyol., 22(4): 274-278.

Lombarte, A.; Rufino, M. M. and Sánchez, P. (2006). Statolith identification of Mediterranean Octopodidae, Sepiidae, Loliginidae, Ommastrephidae and Enoploteuthidae based on warp analyses. J Mar. Biol. Assoc. UK., 86(04): 767771.

Lord, C.; Morat, F.; Lecomte-Finiger, R. and Keith, P. (2012). Otolith shape analysis for three Sicyopterus (Teleostei: Gobioidei: Sicydiinae) species from New Caledonia and Vanuatu. Eniron. Biol.Fish., 93(2): 209-222.

Lychakov, D.; Rebane, Y.; Lombarte, A.; Fuiman, L. and Takabayashi, A. (2006). Fish otolith asymmetry: morphometry and modeling., Hearing Res., 219(1): 111.

Mahé, K.; Aumond, Y.; Rabhi, K.; Elleboode, R.; Bellamy, E. and Huet, J. (2017). Relationship between somatic growth and otolith growth: a case study of the ornate jobfish Pristipomoides argyrogrammicus from the coast of Réunion (SW Indian Ocean). African journal of marine science, Afr. J Mar. Sci., 39(2): 145151.

Mahe, K.; Evano, H.; Mille, T.; Muths, D. and Bourjea, J. (2016). Otolith shape as a valuable tool to evaluate the stock structure of swordfish Xiphias gladius in the Indian Ocean. Afr. J Mar. Sci., 38(4): 457-464.

Mahé, K.; Ider, D.; Massaro, A.; Hamed, O.; Jurado-Ruzafa, A. Gonçalves, P. (2018b). Directional bilateral asymmetry in otolith morphology may affect fish stock discrimination based on otolith shape analysis. ICES J Mar. Sci., 76(1): 232-243.

Mahe, K.; Villanueva, M.; Vaz, S., Coppin, F.; Koubbi, P. and Carpentier, A. (2014). Morphological variability of the shape of striped red mullet Mullus surmuletus in relation to stock discrimination between the Bay of Biscay and the eastern English Channel. J Fish. Biol., 84(4): 1063-1073.

Mapp, J.; Hunter, E.; Van Der Kooij, J.; Songer, S. and Fisher, M. (2017). Otolith shape and size: the importance of age when determining indices for fish-stock separation. Fish. Res., 190: 43-52. 
Mehanna, S.; Jawad, L.; Ahmed, Y.; Abu El-Regal, M. and Dawood, D. (2016). Relationships between fish size and otolith measurements for Chlorurus sordidus (Forsskål, 1775) and Hipposcarus harid (Forsskål, 1775) from the Red Sea coast of Egypt. J Appl. Ichthyol., 32: 356-358.

Mohammad, A.S. (2007): Population Dynamics and Stock Assessment of some species of genus Cephalopholis and genus Variola from the red sea, Egypt. MSc., Thesis, Assiut University, Egypt.

Morat, F.; Letourneur, Y.; Nérini, D.; Banaru, D. and Batjakas, I. E. (2012). Discrimination of red mullet populations (Teleostean, Mullidae) along multispatial and ontogenetic scales within the Mediterranean basin on the basis of otolith shape analysis. Aquat. Living RES., 25(1): 27-39.

Nolf, D. (1985). Otolithi piscium: Handbook of Paleoichthyology, v. 10. Stuttgart, New York: Gustav Fischer.

Osman, A. G. M. (2000). Taxonomical and Biological studies of some species of genus Epinephelus (Family: Serranidae) from the Red Sea, Egypt. M. Sc. Thesis, Al-Azhar Univ., Cairo.

Osman, A.; Farrag, M.; Mehanna, S. and Osman, Y. (2018). Use of otolithic morphometrics and ultrastructure to identify three goatfish species (Family: Mullidae) from the northern Red Sea, Hurghada, Egypt. Iranian Journal of Fisheries Sciences. Iran. J Fish. Scsi. DOI: 10.22092/ijfs.2018.120044.

Parisi-Baradad, V.; Lombarte, A.; García-Ladona, E.; Cabestany, J.; Piera, J. and Chic, O. (2005). Otolith shape contour analysis using affine transformation invariant wavelet transforms and curvature scale space representation. Mar. Fresh. RES., 56(5): 795-804.

Ponton, D. (2006). Is geometric morphometrics efficient for comparing otolith shape of different fish species? J Morphol., 267(6): 750-757.

Radhakrishnan, K.; Li, Y.; Jayalakshmy, K.; Liu, M.; Murphy, B. R. and Xie, S. (2012). Application of otolith shape analysis in identifying different ecotypes of Coilia ectenes in the Yangtze Basin, China. Fish. Res., 125: 156-160.

Randall, J. E. and Ben-Tuvia, A. (1983). A review of the groupers (Pisces: Serranidae: Epinephelinae) of the Red Sea, with description of a new species of Cephalopholis. B Mar. Sci., 33(2): 373-426.

Reichenbacher, B.; Kamrani, E.; Esmaeili, H. R. and Teimori, A. (2009). The endangered cyprinodont Aphanius ginaonis (Holly, 1929) from southern Iran is a valid species: evidence from otolith morphology. Eniron. Biol. Fish., 86(4): 507.

Rohlf, F. J. (2006). tpsDig, version 2.10. http://life. bio. sunysb. edu/morph/index. html.

Sadighzadeh, Z.; Tuset, V. M.; Valinassab, T.; Dadpour, M. R. and Lombarte, A. (2012). Comparison of different otolith shape descriptors and morphometrics for the identification of closely related species of Lutjanus spp. from the Persian Gulf. Mar. Biol. Res., 8(9): 802-814.

Sadighzadeh, Z.; Valinassab, T.; Vosugi, G.; Motallebi, A.; Fatemi, M. R.; Lombarte, A. (2014). Use of otolith shape for stock identification of John's snapper, Lutjanus johnii (Pisces: Lutjanidae), from the Persian Gulf and the Oman Sea. Fish. Res., 155: 59-63.

Shepard, K. E.; Patterson, W. F. and De Vries, D. A. (2010). Trends in Atlantic contribution to mixed-stock king mackerel landings in south Florida inferred from otolith shape analysis. Mar. Coast. Fish., 2(1): 195-204. 
Short, J. A.; Gburski, C. M. and Kimura, D. K. (2006). Using otolith morphometrics to separate small walleye Pollock Theragra chalcogramma from Arctic Cod Boreogadus saida in mixed samples. Alas. Fish. Res. Bull., 12(1): 147-152.

Škeljo, F.; Ferri, J.; Brčić, J.; Petrić, M. and Jardas, I. (2012). Age, growth and utility of otolith morphometrics as a predictor of age in the wrasse Coris julis (Labridae) from the eastern Adriatic Sea. Sci. Mar., 76(3): 587-595.

Sparre, P.; Ursin, E. and Venema, S. (1989). Introduction to tropical fish stock assessment. Part 1. Manual. FAO Fish. Tech. paper (306). Revsion, 2. Rome, FAO. 1998: 407 p.

Summerfelt, R. and Hall, G. (1987). Age and growth offish. Paper presented at the Proceedings of the International Symposium on the Age and Growth of Fish, Des Moines, Iowa. Iowa State University Press, Ames, Iowa, USA.

Treacy, S. D. and Crawford, T.W. (1981). Retrieval of otoliths and statoliths from gastrointestinal contents and scats of marine mammals, Journal of Wildlife Management, 45: 990-993. doi: 10.2307/3808110

Tripple, E. A. and Beamish, F.W. H. (1987). Characterizing piscivory from ingested remains, Transaction of the American Fisheries Society, 116: 773-776. doi: 10.1577/15488659(1987) 116<773:CPFIR>2.0.CO;2

Tuset, V.; Lozano, I.; Gonzalez, J.; Pertusa, J. and García-Díaz, M. (2003b). Shape indices to identify regional differences in otolith morphology of comber, Serranus cabrilla (L., 1758). J. Appl. Ichthyo., 19(2): 88-93.

Tuset, V. M.; Lombarte, A. and Assis, C. A. (2008). Otolith atlas for the western Mediterranean, north and central eastern Atlantic. Sci. Mar., 72(S1): 7-198.

Tuset, V. M.; Lombarte, A.; Gonzalez, J.; Pertusa, J. and Lorente, M. (2003a). Comparative morphology of the sagittal otolith in Serranus spp. J Fish. Biol., 63(6): 1491-1504.

Wakefield, C. B.; Williams, A. J.; Newman, S. J.; Bunel, M.; Dowling, C. E. and Armstrong, C. A (2014). Rapid and reliable multivariate discrimination for two cryptic Eteline snappers using otolith morphometry. Fish. Res., 151: 100-106.

Yilmaz, S.; Yazicioglu, O.; Saygin, S. A. and Polat, N. (2014). Relationships of Otolith Dimensions with Body Length of European Perch, Perca fluviatilis L., 1758 From Lake Ladik, Turkey. Pak. J Zool., 46(5): 1231-1238.

Zhang, C.; Ye, Z.; Panhwar, S. and Shen, W. (2013). Stock discrimination of the Japanese Spanish mackerel (Scomberomorus niphonius) based on the otolith shape analysis in the Y ellow S ea and B ohai S ea. J Appl. Ichthylo., 29(2): 368-373.

Zhuang, L.; Ye, Z. and Zhang, C. (2015). Application of otolith shape analysis to species separation in Sebastes spp. from the Bohai Sea and the Yellow Sea, northwest Pacific. Environ. Biol. Fish., 98(2): 547-558.

Zischke, M. T.; Litherland, L.; Tilyard, B. R.; Stratford, N. J.; Jones, E. L. and Wang, Y. G. (2016). Otolith morphology of four mackerel species (Scomberomorus spp.) in Australia: Species differentiation and prediction for fisheries monitoring and assessment. Fish. Res., 176, 39-47.

Zorica, B.; Sinovčić, G. and Keč, V. Č. (2010). Preliminary data on the study of otolith morphology of five pelagic fish species from the Adriatic Sea (Croatia). Acta Adriat., 51(1): 89. 